Research Article

\title{
Mg-Al/Biochar Composite with Stable Structure for Malachite Green Adsorption from Aqueous Solutions
}

\author{
Arini Fousty Badri, Patimah Mega Syah Bahar Nur Siregar², Neza Rahayu Palapaㄹ, \\ Risfidian Mohadi², Mardiyanto Mardiyanto ${ }^{3}$, Aldes Lesbani ${ }^{1,4, *)}$ \\ ${ }^{1}$ Graduate School, Faculty of Mathematics and Natural Sciences, Universitas Sriwijaya, \\ Jl. Padang Selasa No. 524 Ilir Barat 1, Palembang-South Sumatera, Indonesia. \\ ${ }^{2}$ Department of Chemistry, Faculty of Mathematics and Natural Sciences, Universitas Sriwijaya, \\ Jl. Palembang-Prabumulih, Km. 32, Ogan Ilir 30662, South Sumatera, Indonesia. \\ ${ }_{3}^{3}$ Department of Pharmacy, Faculty of Mathematics and Natural Sciences, Universitas Sriwijaya, \\ Jl. Palembang-Prabumulih, Km. 32, Ogan Ilir 30662, South Sumatera, Indonesia. \\ ${ }^{4}$ Research Center of Inorganic Materials and Complexes, Faculty of Mathematics and Natural Sciences, \\ Universitas Sriwijaya, Jl. Padang Selasa Bukit Besar Palembang 30139, South Sumatera, Indonesia.
}

Received: $2^{\text {nd }}$ February 2021; Revised: $16^{\text {th }}$ March 2021; Accepted: $17^{\text {th }}$ March 2021

Available online: 19th March 2021; Published regularly: March 2021

\section{Abstract}

Mg-Al-layered double hydroxide (LDH) was fabricated using a coprecipitation method at $\mathrm{pH} 10 . \mathrm{Thereafter}, \mathrm{Mg}$ $\mathrm{Al}-\mathrm{LDH}$ was impregnated with biochar to manufacture a $\mathrm{Mg}$-Al/Biochar composite. The composite was characterized using powder X-ray diffraction (XRD), Fourier-transform infrared (FTIR) spectroscopy, $\mathrm{N}_{2}$ adsorptiondesorption, thermogravimetry-differential thermal analysis (TG-DTA), and scanning electron microscopy (SEM) experiments, and was subsequently used for malachite green (MG) adsorption. MG adsorption experiments were performed in a batch system, and the effects of temperature and adsorption kinetic and isotherm parameters on the adsorption process were analyzed. The stability of $\mathrm{Mg}-\mathrm{Al} / \mathrm{Bioch}$ ar was evaluated using regeneration experiments over three cycles. The peaks at $11.47^{\circ}(003), 22.86^{\circ}(002), 34.69^{\circ}(012)$, and $61.62^{\circ}(116)$, in the XRD profile of $\mathrm{Mg}-\mathrm{Al} / \mathrm{Biochar}$ suggested that $\mathrm{Mg}-\mathrm{Al} / \mathrm{Bioch}$ ar was successfully fabricated. The surface area of $\mathrm{Mg}-\mathrm{Al} / \mathrm{Bioch} a r$ was up to five times larger than that of pristine $\mathrm{Mg}-\mathrm{Al}-\mathrm{LDH}$. The adsorption of MG on Mg-Al/Biochar was dominated by interactions at the surface of the adsorbent and was classified as physical adsorption; moreover the maximum adsorption capacity of Mg-Al/Biochar was $70.922 \mathrm{mg} / \mathrm{g}$. Furthermore, the MG removal of Mg-Al/Biochar during three successive adsorption cycles (i.e. $66.73 \%, 65.57 \%$, and $65.77 \%$ for the first, second, and third adsorption cycle) did not change significantly, which indicated the stable structure of the adsorbent.

Copyright (C 2021 by Authors, Published by BCREC Group. This is an open access article under the CC BY-SA License (https://creativecommons.org/licenses/by-sa/4.0).

Keywords: Malachite Green; Layered Double Hydroxide; Mg-Al; Biochar; Mg-Al/Biochar Adsorption

How to Cite: A.F. Badri, P.M.S.B.N. Siregar, N.R. Palapa, R. Mohadi, M. Mardiyanto, A. Lesbani (2021). MgAl/Biochar Composite with Stable Structure for Malachite Green Adsorption from Aqueous Solutions. Bulletin of Chemical Reaction Engineering \& Catalysis, 16(1), 149-160 (doi:10.9767/bcrec.16.1.10270.149-260)

Permalink/DOI: https://doi.org/10.9767/bcrec.16.1.10270.149-160

\section{Introduction}

The use of synthetic dyes in industries, such as: the textile, paint, leather, photography pa-

* Corresponding Author.

Email: aldeslesbani@pps.unsri.ac.id (A. Lesbani) per, cosmetic, and rubber industries, has increased significantly in the past decade owing to the use of bright and appealing materials [1-3]. However, such industries generate wastes that pollute the aquatic environments they are released into [4]. Because pollutant dyes affect hu- 
man health and the flora and fauna of ecosystems [5], such dyes should be removed before releasing industrial waste in aquatic systems. Researchers have explored several methods for dye removal from aqueous solutions, including oxidation, photodegradation, membrane separation, biological processes, and adsorption [69]. Among all methods, adsorption is the most suitable owing to its high speed, high efficiency, ease of use, and low cost [3]. However, adsorption efficiency depends on the properties and quality of the adsorbents used for dye removal from aqueous solutions. Adsorbents are typically classified into organic and inorganic. Organic adsorbents, such as agricultural biomass, algae, chitin, chitosan, and cellulose, are commonly found in the environment [10-13]. Adsorption using organic adsorbents primarily depends on the functional groups that act as active sites. Inorganic adsorbents are also commonly found in the environment or can be synthesised, and the most frequently used inorganic adsorbents include bentonite, zeolite, kaolinite, montmorillonite, and layered double hydroxides (LDHs) [14-16].

$\mathrm{LDHs}$ are typical composites featuring positively charged brucite-like layers and twodimensional nanostructures [17-18]. Moreover, LDHs can be modified to customize and improve their properties for specific applications. LDHs have been used as efficient adsorbents for dye removal from aqueous solutions. Ouassif et al. [19] used $\mathrm{ZnAl} \mathrm{LDH} \mathrm{for} \mathrm{tartrazine} \mathrm{dye} \mathrm{removal}$ and achieved an adsorption capacity of 99.5 $\mathrm{mg} / \mathrm{g}$ after $60 \mathrm{~min}$ at $\mathrm{pH}$ 5.8. Sa et al. [20] used CaAl-LDH-NO ${ }_{3}$ to adsorb Sunset Yellow FCF at a $\mathrm{pH}$ of 4 and reported a maximum adsorption capacity $\left(q_{\max }\right)$ of $398.41 \mathrm{mg} / \mathrm{g}$. Lesbani et al. [21] used $\mathrm{CaAl} \mathrm{LDH}$ to adsorb methylene blue and achieved a $q_{\max }$ value of $8.27 \mathrm{mg} / \mathrm{g}$. Calcined $\mathrm{MgAl}-\mathrm{CO}_{3} \mathrm{LDH}$ was used to remove indigo carmine dye from aqueous solutions by adjusting the $\mathrm{pH}$, temperature, and contact time. The adsorption capacity of calcined $\mathrm{MgAl}-\mathrm{CO}_{3} \mathrm{LDH}$ was $87.92 \mathrm{mg} / \mathrm{g}$ at $\mathrm{pH} 8.8$ after $40 \mathrm{~min}$ [22]. Lafi et al. [23] fabricated Mg-Al LDH and used it as adsorbent for Congo red. The adsorption data fit the Langmuir adsorption isotherm model, and the reported $q_{\max }$ value was 111.11 $\mathrm{mg} / \mathrm{g}$ at $\mathrm{pH}$ 7.7.

Previous studies have indicated that the adsorption capacity of $\mathrm{LDHs}$ for dyes was limited. Furthermore, LDH modification was required to increase the adsorption capacity of $\mathrm{LDHs}$ for dyes. The modification of LDH and carbonbased materials has been increasingly studied, and many researchers have used modified $\mathrm{LDHs}$ to remove organic pollutants from wastewater. $\mathrm{Hu}$ et al. [24] reported that a $\mathrm{NiFe}-\mathrm{LDH}$ nanosheet/carbon fibre nanocomposite was effective for removing Congo red and methyl orange from aqueous solutions. Their results demonstrated that modification increased the adsorption capacity of $\mathrm{NiFe}-\mathrm{LDH}$ for methyl orange and Congo red from 22.2 to $232.6 \mathrm{mg} / \mathrm{g}$ and from 103.7 to $448.4 \mathrm{mg} / \mathrm{g}$, respectively. Meili et al. [25] fabricated MgAlLDH/Biochar composites using pure bovine bone biochar and used them for methylene blue adsorption. The adsorption data fit the Langmuir isotherm and pseudo-second-order (PSO) kinetic models, and the $q_{\max }$ value of the composites at $40{ }^{\circ} \mathrm{C}$ ranged between 46.3 and $406.47 \mathrm{mg} / \mathrm{g}$. Zubair et al. [26] reported that the adsorption capacity of MgAl-LDH/Biochar composites for methylene blue (302.75 mg/g after $180 \mathrm{~min}$ ) was higher than those of pristine biochar (206.61 $\mathrm{mg} / \mathrm{g}$ after $480 \mathrm{~min}$ ) and pristine $\mathrm{MgAl}$ LDH (244.47 mg/g after $480 \mathrm{~min})$. Amin et al. [27] reported that the Freundlich $q_{\max }$ value of NiZnFe-LDH composites with date palm biochar and carbon nanotubes for RB5 dye (121 $\mathrm{mg} / \mathrm{g}$ ) was higher than that of pristine NiZnFeLDH $(63.22 \mathrm{mg} / \mathrm{g})$. Palapa et al. [28] fabricated a $\mathrm{CuAl}-\mathrm{LDH} /$ Biochar composite using rice husk biochar and achieved a $q_{\max }$ of $470.96 \mathrm{mg} / \mathrm{g}$, which was higher than that of pristine $\mathrm{CuAl}$ LDH $(59.523 \mathrm{mg} / \mathrm{g})$.

The aforementioned studies indicated that LDH modification can be used to increase the adsorption capacity of $\mathrm{LDHs}$ for dyes. Because malachite green (MG), which is a synthetic cationic dye (Figure 1), cannot be degraded by microbes in aquatic systems, its removal using other methods is critical. In this study, Mg-AlLDH was impregnated with biochar to fabricate a Mg-Al/Biochar composite with high adsorption capacity. Moreover, biochar impregnation increased LDH stability and improved adsorbent reusability. MG adsorption was performed in a batch system, and the effects of

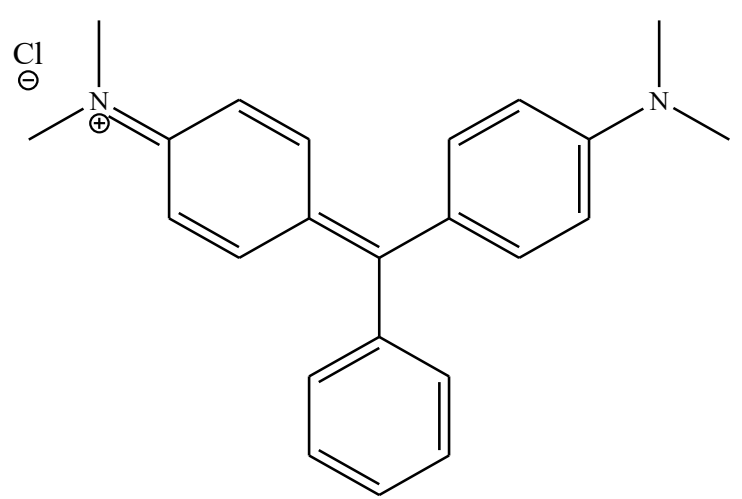

Figure 1. Chemical structure of malachite green. 
contact time and isotherm, desorption, and regeneration parameters on the adsorption process were investigated.

\section{Materials and Methods}

\subsection{Chemical and Instrumentations}

Chemicals were obtained from magnesium nitrate, aluminum nitrate, sodium hydroxide, acetone, and hydrochloric acid which purchased from Merck and Sigma-Aldrich and the rice husk Biochar was acquired by Bukata Organic Indonesia. Material was characterized using XRay powder Rigaku Miniflex-6000. IR spectrum was recorded by using FTIR Shimadzu Pestige21 at wavenumber $400-4000 \mathrm{~cm}^{-1}$. Surface area, pore diameter, and pore size were measured by BET method by Micromeritic ASAP and sample was degassed using liquid nitrogen and material thermal analysis was studied by TG-DTA Shimadzu was used to study. The morphology of the materials were tested by SEM Quanta-650 OXFORD Instrument. Concentration of MG was analyzed using Biobase BK-UV $1800 \mathrm{PC}$ spectrophotometer at $617 \mathrm{~nm}$.

\subsection{Preparation of Mg-Al-LDH and Composite $\mathrm{Mg}-\mathrm{Al} / \mathrm{Biochar}$}

$\mathrm{Mg}-\mathrm{Al}-\mathrm{LDH}$ was prepared by dropping a solution $0.75 \mathrm{MMg}\left(\mathrm{NO}_{3}\right)_{2} .6 \mathrm{H}_{2} \mathrm{O}(100 \mathrm{~mL})$ to 0.25 $\mathrm{MAl}\left(\mathrm{NO}_{3}\right)_{3} .9 \mathrm{H}_{2} \mathrm{O}(100 \mathrm{~mL})$. To achieve $\mathrm{pH} 10$, $\mathrm{NaOH}$ was added in to the mixture and stirred for $30 \mathrm{~min}$. The mixture was heated at $80{ }^{\circ} \mathrm{C}$ overnight. The obtained precipitate was dried in oven at $100{ }^{\circ} \mathrm{C}$ for 24 hours. The $\mathrm{Mg}$-Al/Biochar was produced by mixing magnesium nitrate and aluminum nitrate (3:1). The mixture was gently stirred for 1 hour. The reaction mixture was poured with $1 \mathrm{~g}$ of biochar and reaction was mixed by constant stirring under $\mathrm{pH} 10$. The mixture was heat at $90{ }^{\circ} \mathrm{C}$ for 3 days and dried at $110{ }^{\circ} \mathrm{C}$ for $5-6$ days prior characterization.

\subsection{Adsorption Process}

MG adsorption experiments were performed at adsorption times in the range of 10-200 min, MG concentrations in the range of $10-200 \mathrm{~min}$, and temperatures in the range of $30-60{ }^{\circ} \mathrm{C}$. The concentration of $\mathrm{MG}$ in the filtrate after adsorption was analyzed using the aforementioned UV-Vis spectrophotometer.

\subsection{Desorption and Regeneration Experiments}

MG desorption from the Mg-Al/Biochar composite was evaluated using several reagents, namely water, acetone, $\mathrm{HCl}$, and $\mathrm{NaOH}$, and the optimal desorption reagents were subsequently used to regenerate the adsorbent. After desorption, the adsorbent was collected and dried at $100{ }^{\circ} \mathrm{C}$. Thereafter, the regenerated adsorbent was reused for three adsorption cycles. MG dye removal experiments were performed using previously reported optimal time and temperature values.

\section{Results and Discussion}

The XRD profiles of Mg-Al-LDH, biochar, and $\mathrm{Mg}-\mathrm{Al} /$ Biochar are presented in Figure 2. The formation of Mg-Al-LDH was confirmed by the presence of the diffraction peaks at $11.47^{\circ}$, $22.86^{\circ}, 34.69^{\circ}, 60.33^{\circ}$, and $61.62^{\circ}$, which corresponded to the (003), (002), (012), (110), and (116) planes of LDHs comprising divalent and trivalent ions (JCPDS no. 70-215) [29-30]. The presence of a metal oxide peak at $29.49^{\circ}$ in the XRD pattern of Mg-Al-LDH (Figure 2a) was ascribed to the synthesis conditions [31]. The wide peak in the XRD pattern of rice husk biochar (Figure 2b) was attributed to biochar being an organic material consisting mainly of carbon. Moreover, the peaks at approximately $21-26^{\circ}$ in the XRD pattern of biochar were attributed the (002) plane of carbon [32]. The XRD pattern of $\mathrm{Mg}-\mathrm{Al} / \mathrm{Biochar}$ is illustrated in Figure 2c. The peaks at $11.47^{\circ}(003), 22.86^{\circ}$ (002), $34.69^{\circ}(012)$, and $61.62^{\circ}$ (116) confirmed that $\mathrm{Mg}-\mathrm{Al} / \mathrm{Biochar}$ was successfully synthesized.

The $\mathrm{N}_{2}$ adsorption-desorption isotherms of Mg-Al-LDH, biochar, and Mg-Al/Biochar are presented in Figure 3. The adsorption patterns

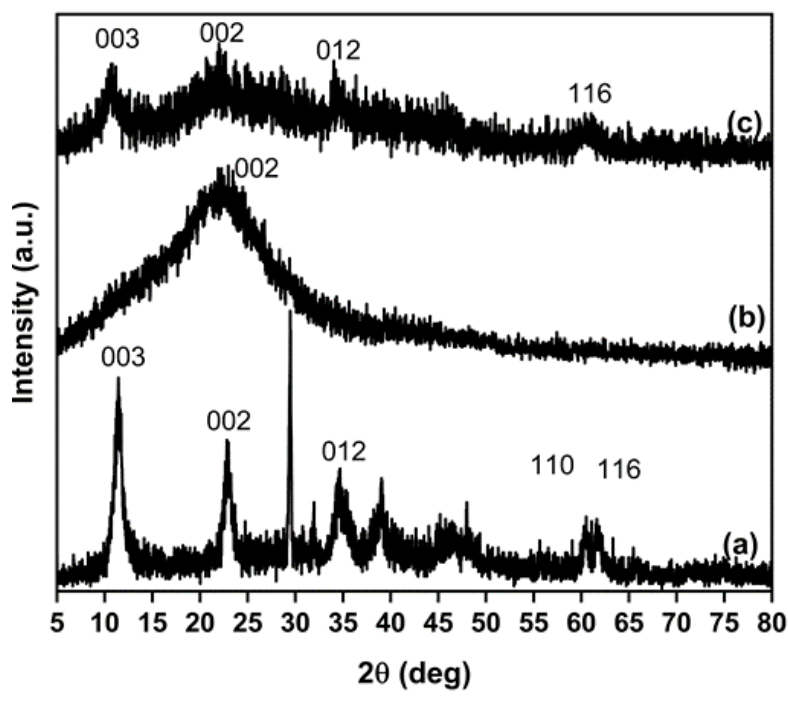

Figure 2. X-ray diffraction patterns of (a) MgAl-layered double hydroxide, (b) biochar, and (c) $\mathrm{Mg}-\mathrm{Al} /$ Biochar. 
of all samples were different from their desorption patterns. All materials presented $\mathrm{H} 2$ type hysteresis loops and, therefore, were classified as mesoporous [33]. The BET surface areas of the adsorbents were calculated using the $\mathrm{N}_{2}$ adsorption-desorption isotherms and the data are summarized in Table 1.

The surface area of $\mathrm{Mg}$-Al/Biochar composite $\left(111.404 \mathrm{~m}^{2} / \mathrm{g}\right)$ was significantly higher than those of $\mathrm{Mg}$-Al-LDH $\left(23.150 \mathrm{~m}^{2} / \mathrm{g}\right)$ and biochar $\left(50.936 \mathrm{~m}^{2} / \mathrm{g}\right)$. Moreover, the pore size and pore volume of the composite were smaller than those of Mg-Al-LDH and biochar because biochar covered the surface of Mg-Al-LDH. These results were consistent with the prediction that when the surface of $\mathrm{Mg}-\mathrm{Al}-\mathrm{LDH}$ was covered by biochar which consists of carbon, adsorption was dominated by physical interactions [34].

The FTIR spectra of the adsorbents are presented in Figure 4. The main vibration at 1381 $\mathrm{cm}^{-1}$ in the FTIR spectrum of Mg-Al-LDH was ascribed to the nitrate ions in the materials used to synthesize Mg-Al-LDH. The stretching vibration at $1635 \mathrm{~cm}^{-1}$ was attributed to the vibration of the $\mathrm{OH}$ group of water. The vibration at $2376 \mathrm{~cm}^{-1}$ was ascribed to the $\mathrm{C}-\mathrm{H}$ bonds of biochar [35]. The vibrations at 3448 and 1635

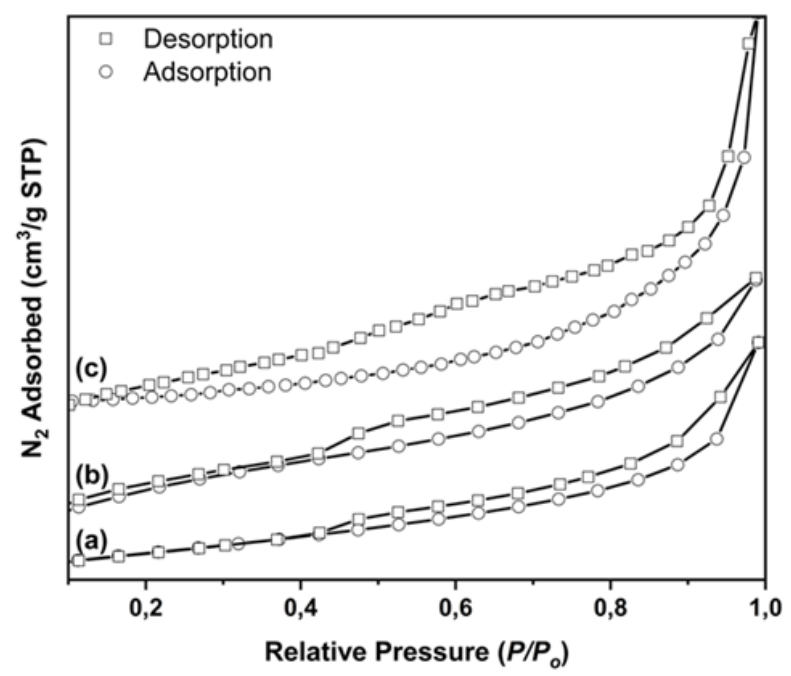

Figure 3. $\mathrm{N}_{2}$ adsorption-desorption isotherms of (a) Mg-Al- layered double hydroxide, (b) biochar, and (c) Mg-Al/Biochar. $\mathrm{cm}^{-1}$ were assigned to the stretching and bending of the $\mathrm{O}-\mathrm{H}$ bonds of water [28]. Conversely, the vibrations at $1381 \mathrm{~cm}^{-1}$ (stretching of $\mathrm{N}-\mathrm{O}$ bonds of nitrate anions), $3447 \mathrm{~cm}^{-1}$ (stretching of $\mathrm{O}-\mathrm{H}$ bonds of physisorbed water), $1010 \mathrm{~cm}^{-1}$ (stretching of $\mathrm{C}-\mathrm{O}$ bonds of biochar), and 1635 $\mathrm{cm}^{-1}$ (stretching of $\mathrm{O}-\mathrm{H}$ bonds of water) in the FTIR spectrum of the Mg-Al/Biochar composite (Figure 4c) indicated that Mg-Al-LDH and biochar formed a composite.

The TG-DTA profiles of Mg-Al-LDH and $\mathrm{Mg}-\mathrm{Al} /$ Biochar are illustrated in Figure 5. The profile of $\mathrm{Mg}$-Al-LDH consisted of three endothermic peaks at 105,330 , and $720^{\circ} \mathrm{C}$, which were assigned to the loss of lattice water, decomposition of nitrates in the interlayer, and destruction of the layered structure, respectively. Conversely, the TG-DTA profile of biochar consisted of two peaks at 110 and $490{ }^{\circ} \mathrm{C}$. The endothermic peak at $110^{\circ} \mathrm{C}$ was attributed to the loss of water in the lattice structure, whereas the exothermic peak at $490{ }^{\circ} \mathrm{C}$ was attributed to the oxidation of organic compounds in biochar [36]. The TG-DTA profile of $\mathrm{Mg}$ $\mathrm{Al} /$ Biochar (Figure 5c) consisted of two endothermic peaks at 110 and $305{ }^{\circ} \mathrm{C}$ and one exothermic peak at $490{ }^{\circ} \mathrm{C}$. These data revealed that the composite consisted of $\mathrm{Mg}-\mathrm{Al}-\mathrm{LDH}$ and

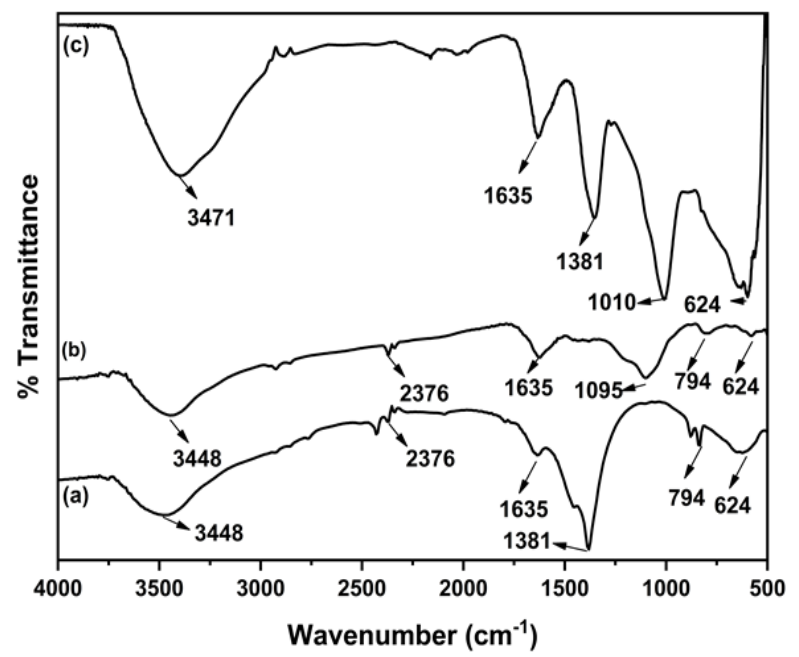

Figure 4. Fourier-transform infrared spectra of (a) Mg-Al- layered double hydroxide, (b) biochar, and (c) Mg-Al/Biochar.

Table 1. Morphology analysis of Mg-Al-LDH, Biochar and Mg-Al/Biochar.

\begin{tabular}{lccc}
\hline Adsorbents & Surface Area $($ BET $)\left(\mathrm{m}^{2 / \mathrm{g}}\right)$ & Pore Volume $(\mathrm{BJH})\left(\mathrm{cm}^{3 / \mathrm{mg}}\right)$ & Pore Diameter $(\mathrm{BJH})(\mathrm{nm})$ \\
\hline Mg-Al-LDH & 23.150 & 0.092 & 36.000 \\
Biochar & 50.936 & 0.025 & 12.087 \\
Mg-Al/Biochar & 111.404 & 0.062 & 10.918 \\
\hline
\end{tabular}


biochar. The exothermic peak was predominant in the TG-DTA profile of the Mg-Al/Biochar composite, probably because the biochar content of the composite was slightly higher than the Mg-Al-LDH content.

The morphologies of the Mg-Al-LDH, biochar, and $\mathrm{Mg}-\mathrm{Al} / \mathrm{biochar}$ are presented in Figure 6. Mg-Al-LDH presented a cubic morpholo-
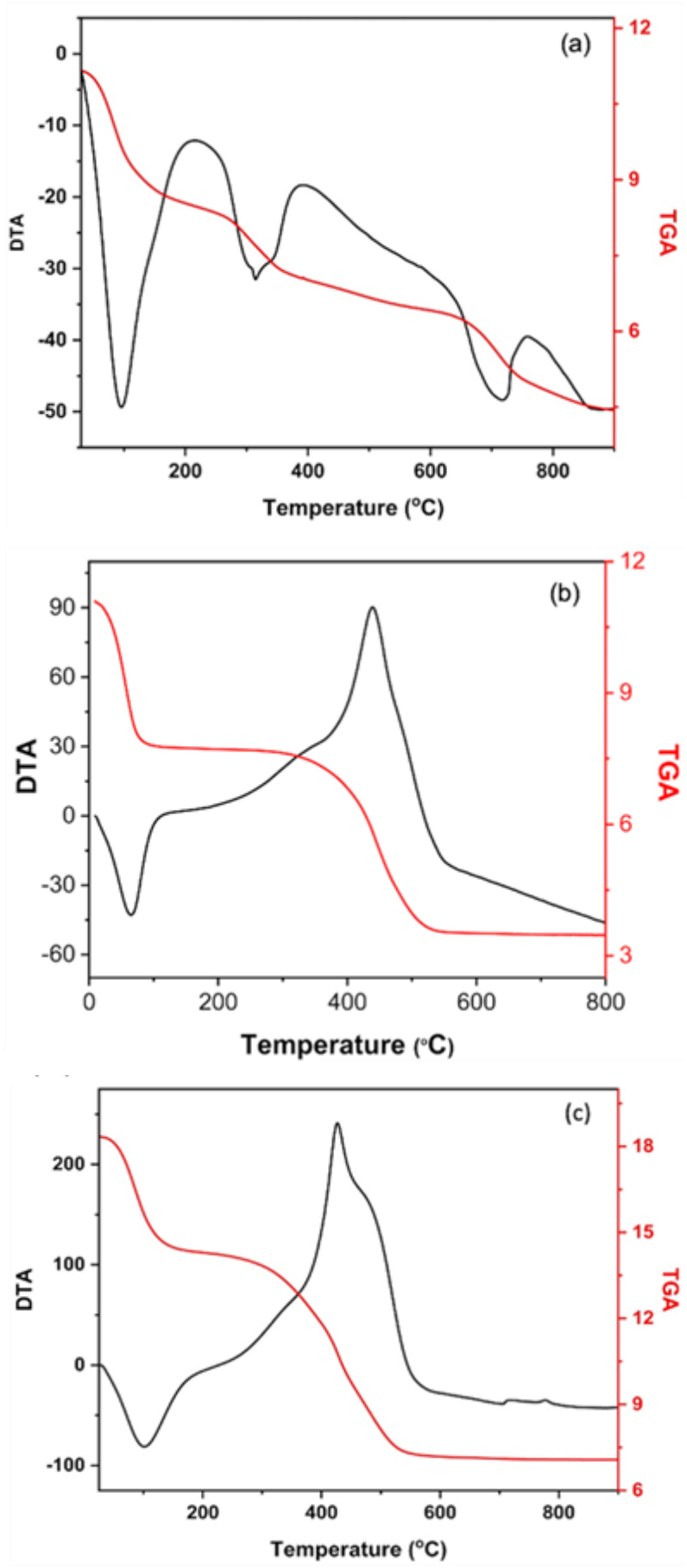

Figure 5. Thermogravimetric analysis (TGA) and differential thermal analysis (DTA) patterns of (a) Mg-Al-layered double hydroxide, (b) biochar, and (c) Mg-Al/Biochar. gy with agglomerated particles scattered on the surface, which was in agreement with the findings of Palapa et al. [37]. Conversely, biochar consisted of sharp and large particles with an irregular porous structure. The morphology of $\mathrm{Mg}$-Al/Biochar was a hybrid of the morphologies of Mg-Al-LDH and biochar; $\mathrm{Mg}-\mathrm{Al} /$ Biochar presented a heterogeneous morphology and the
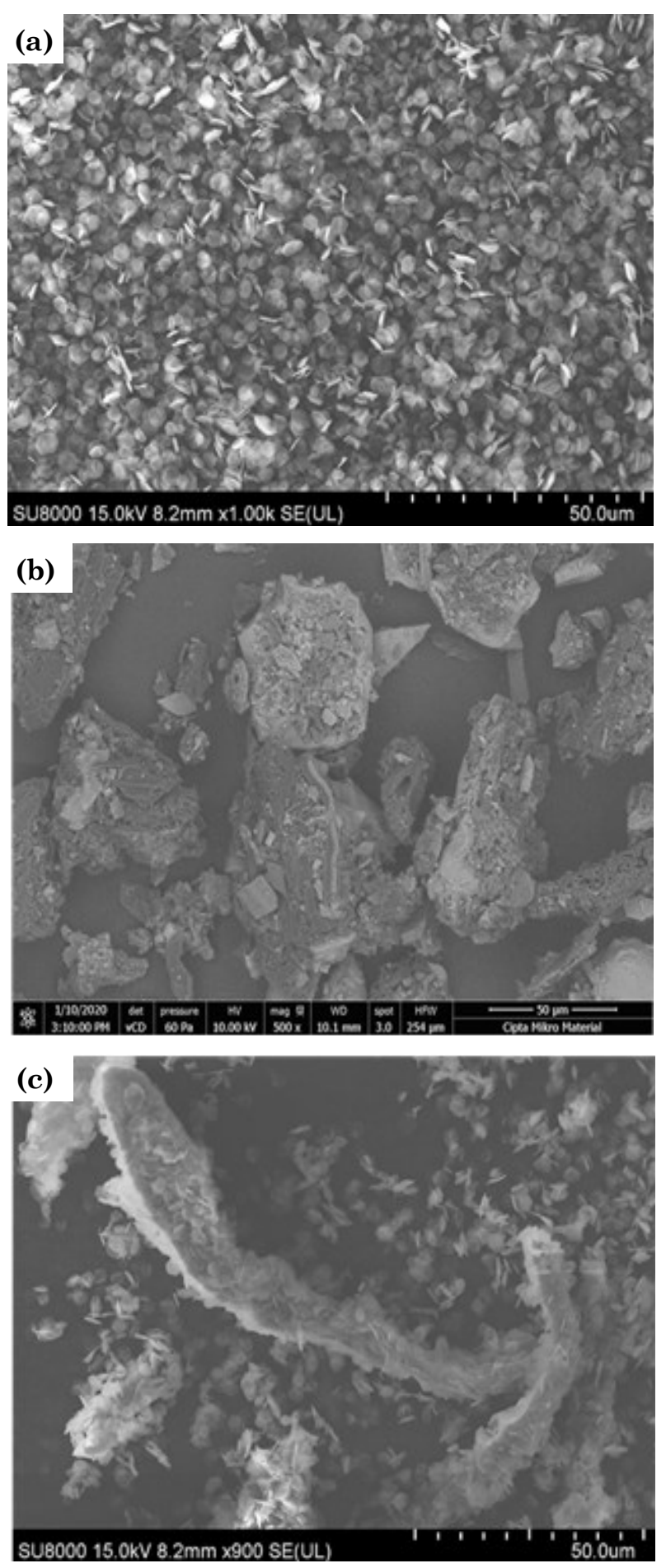

Figure 6. Scanning electron microscopy images of (a) Mg-Al- layered double hydroxide, (b) biochar, and (c) Mg-Al/Biochar. 
particles on its surface were large (Figure 7). $\mathrm{Mg}-\mathrm{Al} /$ Biochar particle size ranged between 0.139-0.341 $\mu \mathrm{m}$; moreover, its particle size distribution was wider than that of pristine $\mathrm{Mg}$ $\mathrm{Al}-\mathrm{LDH}$ and, therefore, the surface area of $\mathrm{Mg}$ -
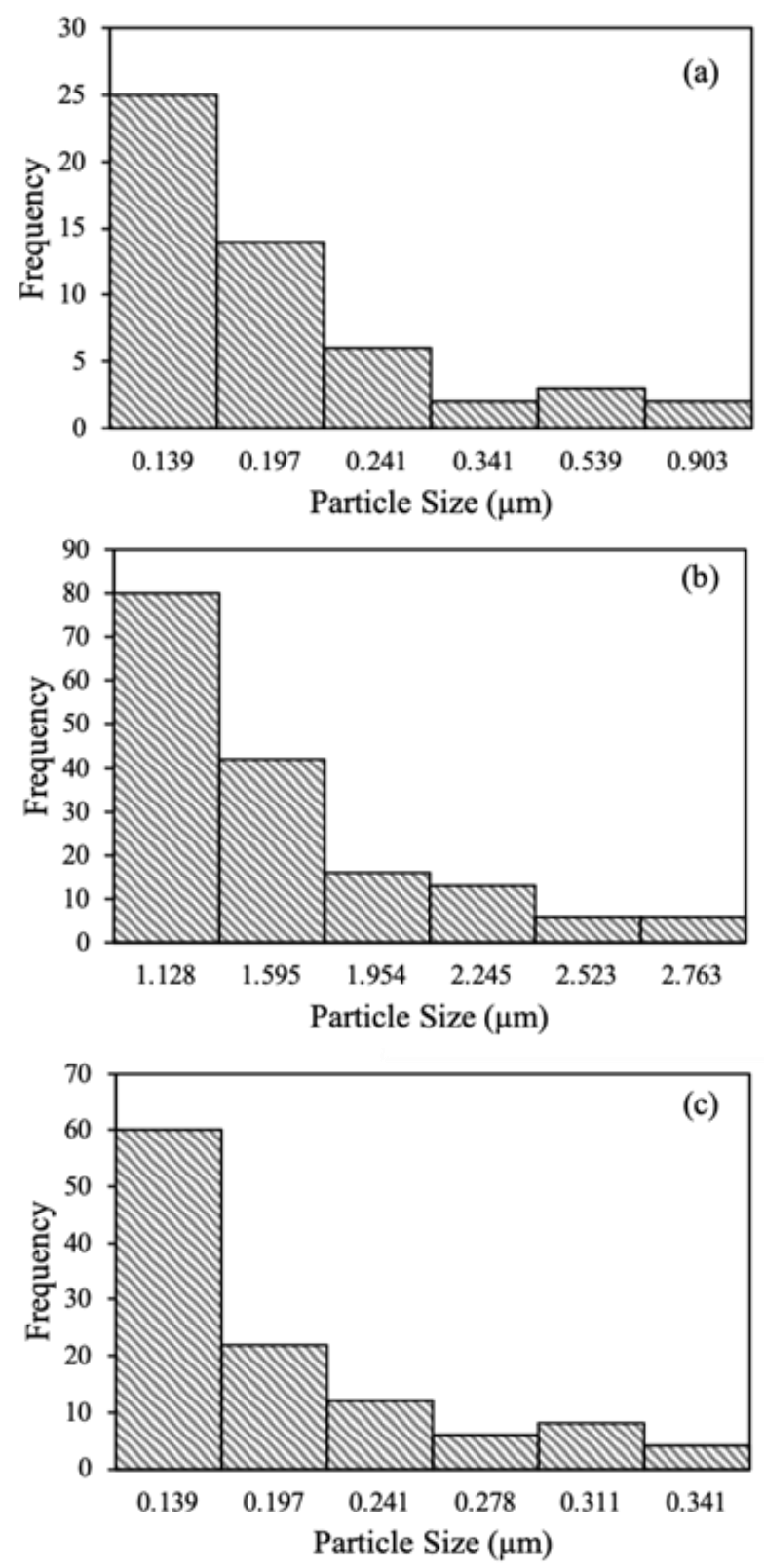

Figure 7. Particle size distribution of (a) MgAl- layered double hydroxide, (b) biochar, and (c) $\mathrm{Mg}-\mathrm{Al} /$ Biochar.
Al/Biochar composite was higher than that of Mg-Al-LDH. Ahmed et al. [38] suggested that the increase in particle size of $\mathrm{Mg}$-Al/Biochar was caused by the pores of biochar particles being well dispersed on the LDH surface, therefore demonstrating that biochar modification was successful.

MG adsorption on Mg-Al-LDH, biochar, and $\mathrm{Mg}-\mathrm{Al} /$ Biochar was analysed using kinetic and isotherm adsorption experiments. The adsorption time ranged between 10-210 min and the kinetic parameters were fitted using pseudofirst-order (PFO) and pseudo-second-order PSO kinetic models [24-39]. The experimental data are presented in Figure 8, and the kinetic parameters are summarized in Table 2 . The data in Table 2 indicated that MG adsorption on $\mathrm{Mg}-\mathrm{Al}-\mathrm{LDH}$, biochar, and Mg-Al/Biochar followed the PSO rather than the PFO kinetic model, and the correlation coefficient $\left(\mathrm{R}^{2}\right)$ for the PSO kinetic model was approximately 1. The PSO reaction constant values suggested that MG adsorption on $\mathrm{Mg}$-Al/Biochar was slower than that on pristine $\mathrm{Mg}-\mathrm{Al}-\mathrm{LDH}$, probably owing to biochar loading on Mg-Al-LDH. The equilibrium absorption capacity of $\mathrm{Mg}$ -

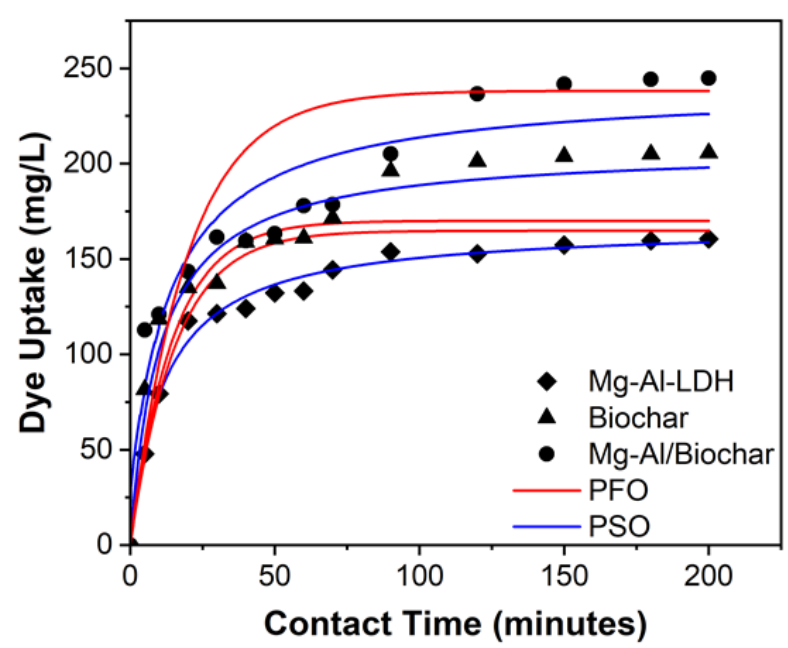

Figure 8. Kinetics of malachite green adsorption on $\mathrm{Mg}$-Al-layered double hydroxide, biochar, and Mg-Al/Biochar; here, PFO and PSO denote pseudo-first- and pseudo-second-order kinetic models, respectively.

Table 2. Adsorption Kinetic of Mg-Al-LDH and Mg-Al/Biochar.

\begin{tabular}{lcccccccccc}
\hline \multirow{2}{*}{$\mathrm{LDH}$} & \multirow{2}{*}{$\begin{array}{c}q_{\mathrm{e}} \\
(\mathrm{mg} / \mathrm{L})\end{array}$} & $\begin{array}{c}\mathrm{Co} \\
(\mathrm{mg} / \mathrm{L})\end{array}$ & $\begin{array}{c}q_{\mathrm{e}} \\
(\mathrm{mg} / \mathrm{g})\end{array}$ & $\begin{array}{c}k_{1} \\
\left(\mathrm{~min}^{-1}\right)\end{array}$ & $\mathrm{R}^{2}$ & & $\begin{array}{c}q_{\mathrm{e}} \\
(\mathrm{mg} / \mathrm{L})\end{array}$ & $\begin{array}{c}k_{2} \\
\left(\mathrm{~min}^{-1}\right)\end{array}$ & $\mathrm{R}^{2}$ \\
\hline $\mathrm{Mg}-\mathrm{Al}$ & 80.276 & 200 & 52.674 & 0.003 & 0.9612 & & 85.470 & 0.001 & 0.999 \\
Biochar & 93.448 & 200 & 77.553 & 0.030 & 0.9763 & & 100.000 & 0.001 & 0.995 \\
$\mathrm{Mg}-\mathrm{Al} /$ Biochar & 122.379 & 200 & 125.545 & 0.029 & 0.9278 & & 133.333 & 0.0004 & 0.983 \\
\hline
\end{tabular}


Al/Biochar was higher than those of $\mathrm{Mg}-\mathrm{Al}$ $\mathrm{LDH}$ or biochar because adsorption occurred at the surface sites.

The isotherm fit parameters for the MG adsorption on Mg-Al-LDH, biochar, and $\mathrm{Mg}$ Al/Biochar are illustrated in Figure 9. The ad-
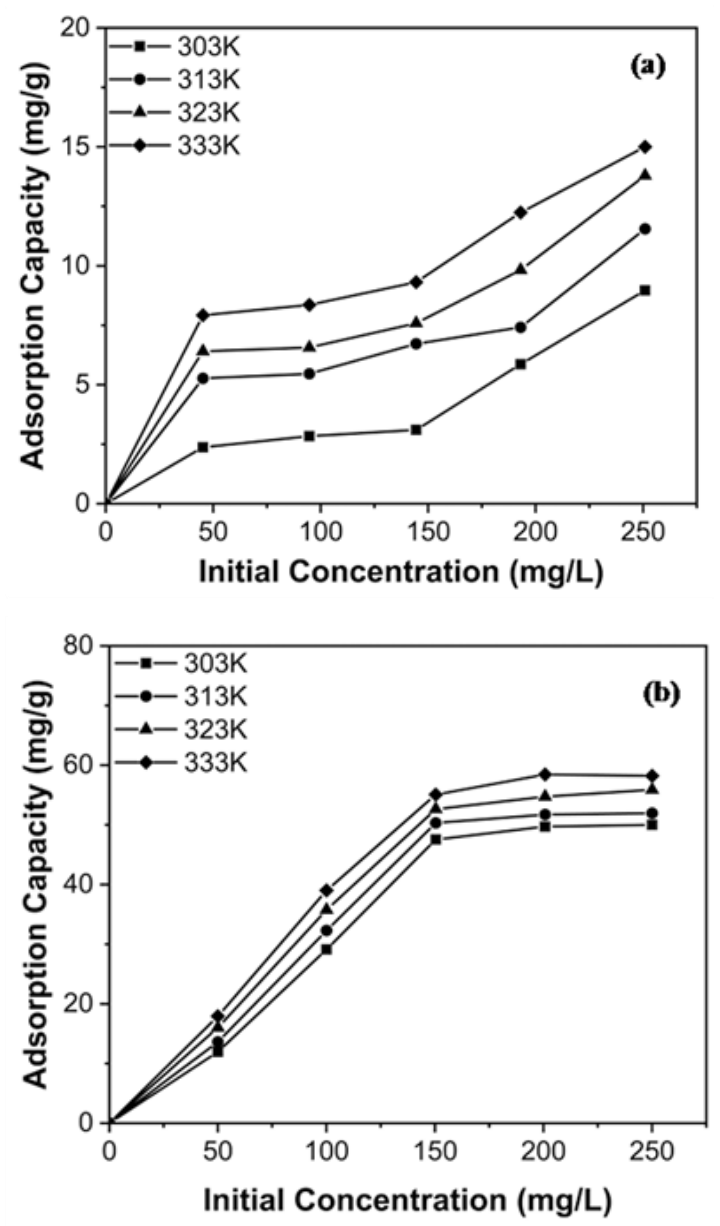

sorption temperature ranged between $30-60{ }^{\circ} \mathrm{C}$ and the initial $\mathrm{MG}$ concentration ranged between $50-250 \mathrm{mg} / \mathrm{L}$. MG adsorption increased significantly as MG concentration was increased from 50 to $150 \mathrm{mg} / \mathrm{L}$ at all temperatures and remained constant after $150 \mathrm{~min}$ of adsorption. MG adsorption at high temperatures was higher than at low temperatures for all adsorbents. The data in Figure 9 were used to calculate the isotherm and thermodynamic adsorption parameters, and the results are summarized in Tables 3 and 4, respectively.

MG adsorption fit the Freundlich isotherm model better than the Langmuir model. The $\mathrm{R}^{2}$ values of all adsorbents for the Freundlich model were higher than those for the Langmuir model. These results indicated that $\mathrm{MG}$ adsorption on $\mathrm{Mg}-\mathrm{Al}-\mathrm{LDH}$, biochar, and $\mathrm{Mg}$ $\mathrm{Al} /$ Biochar was dominated by physical adsorption and depended on the surface area of the

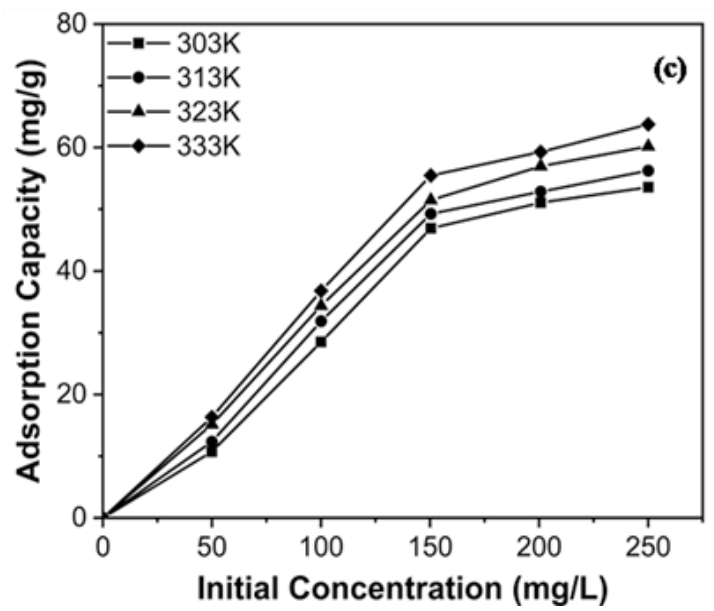

Figure 9. Isotherm parameters for malachite green adsorption on (a) Mg-Al-layered double hydroxide, (b) biochar, and (c) Mg-Al/Biochar.

Table 3. Adsorption malachite green isotherms of Mg-Al-LDH, Biochar and Mg-Al/Biochar.

\begin{tabular}{lccccccc}
\hline \multirow{2}{*}{$\mathrm{LDH}$} & \multicolumn{3}{c}{ Langmuir Constants } & & \multicolumn{3}{c}{ Freundlich Constants } \\
\cline { 2 - 4 } \cline { 6 - 8 } & $q_{\max }$ & $K_{\mathrm{L}}$ & $\mathrm{R}^{2}$ & & $\mathrm{n}$ & $K_{\mathrm{F}}$ & $\mathrm{R}^{2}$ \\
\hline Mg-Al & 44.444 & 0.180 & 0.715 & & 1.194 & 9.456 & 0.996 \\
Biochar & 56.818 & 0.013 & 0.732 & & 0.462 & 18.767 & 0.958 \\
Mg-Al/Biochar & 70.922 & 0.084 & 0.953 & & 4.897 & 25.119 & 0.999 \\
\hline
\end{tabular}

Table 4. The parameters thermodinamic of Adsorption Malachite Green of $\mathrm{Mg} / \mathrm{Al}$, Biochar, and $\mathrm{Mg}$ Al/Biochar.

\begin{tabular}{|c|c|c|c|c|c|c|c|c|c|}
\hline \multirow{2}{*}{$\begin{array}{c}\mathrm{T} \\
(\mathrm{K})\end{array}$} & \multicolumn{3}{|c|}{ Mg-Al-LDH } & \multicolumn{3}{|c|}{ Biochar } & \multicolumn{3}{|c|}{ Mg-Al/Biochar } \\
\hline & $\begin{array}{c}\triangle \mathrm{H} \\
(\mathrm{kJ} / \mathrm{mol})\end{array}$ & $\begin{array}{c}\triangle \mathrm{S} \\
(\mathrm{kJ} / \mathrm{K} / \mathrm{mol})\end{array}$ & $\begin{array}{c}\triangle \mathrm{G} \\
(\mathrm{kJ} / \mathrm{mol})\end{array}$ & $\begin{array}{c}\triangle \mathrm{H} \\
(\mathrm{kJ} / \mathrm{mol})\end{array}$ & $\begin{array}{c}\triangle \mathrm{S} \\
(\mathrm{kJ} / \mathrm{K} / \mathrm{mol})\end{array}$ & $\begin{array}{c}\triangle \mathrm{G} \\
(\mathrm{kJ} / \mathrm{mol})\end{array}$ & $\begin{array}{c}\triangle \mathrm{H} \\
(\mathrm{kJ} / \mathrm{mol})\end{array}$ & $\begin{array}{c}\triangle \mathrm{S} \\
(\mathrm{kJ} / \mathrm{K} / \mathrm{mol})\end{array}$ & $\begin{array}{c}\triangle \mathrm{G} \\
(\mathrm{kJ} / \mathrm{mol})\end{array}$ \\
\hline 303 & & & -3.905 & & & -0.184 & & & -0.189 \\
\hline $\begin{array}{l}313 \\
323 \\
333\end{array}$ & 38.204 & 0.139 & $\begin{array}{l}-5.295 \\
-6.685 \\
-8.075\end{array}$ & 5.531 & 0.019 & $\begin{array}{l}-0.372 \\
-0.561 \\
-0.749\end{array}$ & 7.203 & 0.024 & $\begin{array}{l}-0.433 \\
-0.677 \\
-0.921\end{array}$ \\
\hline
\end{tabular}


adsorbent [40-42]. Although chemical interactions probably occurred during $\mathrm{MG}$ adsorption, the contribution of chemical adsorption was negligible. The adsorption energies of $\mathrm{Mg}-\mathrm{Al}-$ $\mathrm{LDH}$, biochar, and Mg-Al/Biochar (Table 3) further confirmed the predominance of physical adsorption in this study [39]. The MG adsorption capacities of several adsorbents reported in the literature and $\mathrm{Mg}$-Al-LDH and $\mathrm{Mg}$ $\mathrm{Al} /$ Biochar used in this study are summarized in Table 5. The adsorption capacity of $\mathrm{Mg}$-Al$\mathrm{LDH}$ for MG was similar to that of other $\mathrm{LDHs}$ but was slightly lower than those of biomassbased adsorbents. Conversely, the adsorption capacity of $\mathrm{Mg}$-Al/Biochar was higher than those of unmodified LDHs. These results were attributed to the increase in surface area caused by biochar modification and involvement of the active sites of biochar in adsorption.

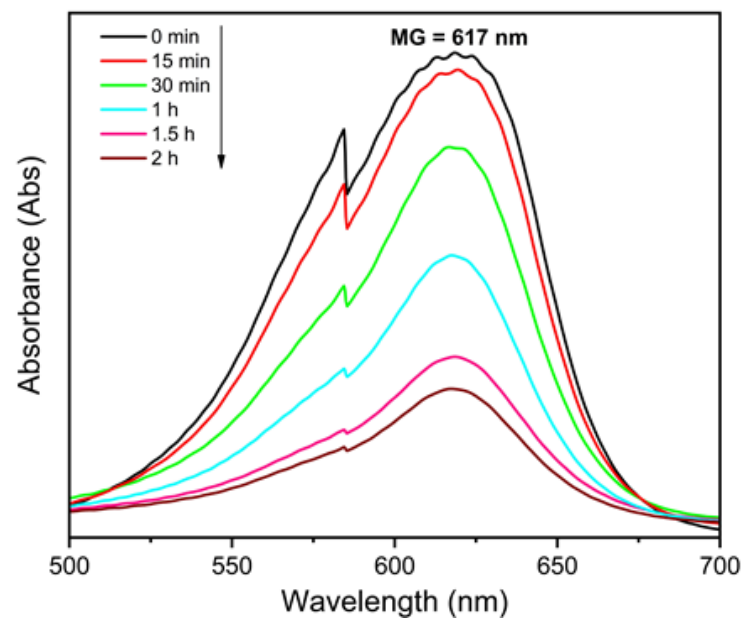

Figure 10. Ultraviolet-visible absorption spectrum for malachite green (MG) adsorption on Mg-Al/Biochar (m = $200 \mathrm{mg}, \mathrm{V}=19.905 \mathrm{~mL}$, Co $=25 \mathrm{mg} / \mathrm{L}$ ).
The UV-Vis spectrum for MG removal using $\mathrm{Mg}-\mathrm{Al} /$ Biochar is presented in Figure 10. The adsorption peak was observed at a wavelength of $617 \mathrm{~nm}$. Moreover, the UV-Vis data revealed that adsorption occurred rapidly when the contact time ranged between 0-60 min and reached an equilibrium when the contact time was extended to 90-120 min; MG concentration decreased from 19.905 to $6.168 \mathrm{mg} / \mathrm{L}$. The mechanism of MG adsorption on $\mathrm{Mg}$-Al/Biochar is presented in Figure 11. Mg-Al/Biochar successfully removed MG, probably via electrostatic attractions and hydrogen bonding, because electrostatic attraction occurred between the active sites of biochar and MG.

MG desorption from $\mathrm{Mg}$-Al-LDH, biochar, and $\mathrm{Mg}-\mathrm{Al} / \mathrm{Biochar}$ was performed to determine the predominant type of adsorbentadsorbate interaction. Desorption was performed using water, hot water, acetone, $\mathrm{HCl}$, and $\mathrm{NaOH}$ as desorption reagents. The experi-

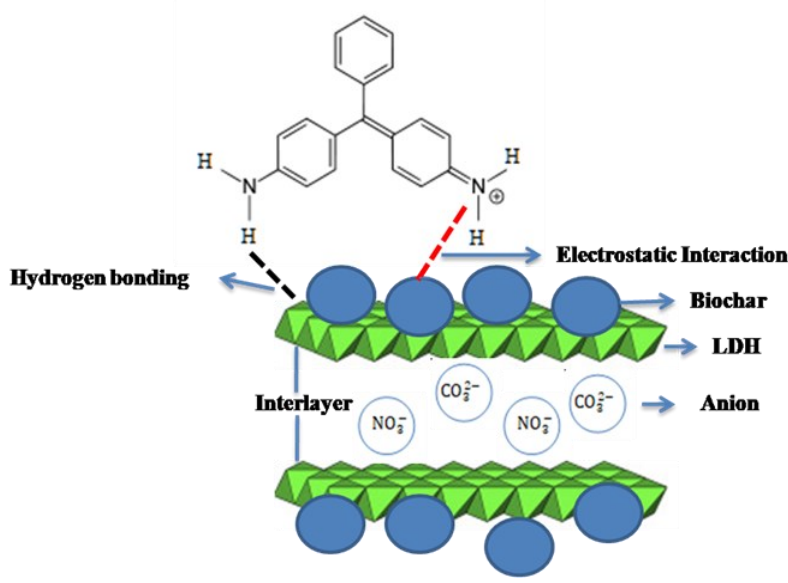

Figure 11. Mechanism of malachite green adsorption on $\mathrm{Mg}-\mathrm{Al} / \mathrm{Biochar}$; here, $\mathrm{LDH}$ denotes layered double hydroxide.

Table 5. Comparison of several adsorbents to remove MG from aqueous solution.

\begin{tabular}{lcc}
\hline Adsorbent & Adsorption Capacity $(\mathrm{mg} / \mathrm{g})$ & Reference \\
\hline Sugarcane bagasse biochar & 10 & {$[43]$} \\
MWCNT-COOH & 11.73 & {$[44]$} \\
C-Zn-Al & 126.58 & {$[45]$} \\
Zn-NR-AC & 59.17 & {$[46]$} \\
ZnO-NR-AC & 20 & {$[46]$} \\
Luffa aegayptica peel & 70.21 & {$[47]$} \\
Peltophorumpterocarpumfruit shells & 62.50 & {$[48]$} \\
Ni/Fe LDH & 6.93 & {$[49]$} \\
Co/Fe LDH & 44.73 & {$[50]$} \\
Cu/Cr LDH & 55.86 & {$[51]$} \\
Mg-Al LDH & 44.444 & This Study \\
Mg-Al/Biochar & 70.922 & This Study \\
\hline
\end{tabular}


mental data (Figure 12) revealed that $\mathrm{HCl}$ was a suitable reagent for $\mathrm{MG}$ desorption from $\mathrm{Mg}$ $\mathrm{Al}-\mathrm{LDH}$ and $\mathrm{Mg}-\mathrm{Al} /$ Biochar. However, the best reagent for MG desorption from biochar was acetone [52]. The optimal desorption using $\mathrm{HCl}$ indicated that a small degree of ionic interaction was present between $\mathrm{MG}$ and $\mathrm{Mg}$-Al-LDH and $\mathrm{Mg}-\mathrm{Al} /$ Biochar. Although physical interactions were predominant in this study, the electrostatic interactions between the positive charges of $\mathrm{MG}$ and the negative charges of $\mathrm{Mg}$ $\mathrm{Al}-\mathrm{LDH}$ and $\mathrm{Mg}-\mathrm{Al} /$ Biochar was still observed to a small degree.

$\mathrm{Mg}-\mathrm{Al}-\mathrm{LDH}$, biochar, and Mg-Al/Biochar regeneration was performed using $\mathrm{HCl}$, acetone, and $\mathrm{HCl}$, respectively. The adsorbents were used for three adsorption cycles as presented in Figure 9. Mg-Al-LDH and biochar were unstable; however, $\mathrm{Mg}$-Al/Biochar was stable for three adsorption cycles without a significant decrease in adsorption capacity (Figure 13). $\mathrm{Mg}$-Al-LDH was exfoliated by $\mathrm{HCl}$ and biochar was destroyed by acetone. Conversely, Mg$\mathrm{Al} /$ Biochar was stable in $\mathrm{HCl}$ and organic solvents; therefore, the structure of $\mathrm{Mg}$-Al/Biochar was stable and its adsorption capacity did not change significantly over three adsorption cycles.

\section{Conclusions}

Mg-Al/Biochar composite was successfully synthesised using $\mathrm{Mg}-\mathrm{Al}-\mathrm{LDH}$ and biochar. The layered structure of $\mathrm{Mg}$-Al/Biochar was confirmed by the peaks at $11.47^{\circ}(003), 22.86^{\circ}$ (002), $34.69^{\circ}(012)$, and $61.62^{\circ}$ (116) in the XRD profile of $\mathrm{Mg}-\mathrm{Al} /$ Biochar. The surface area of $\mathrm{Mg}-\mathrm{Al} /$ Biochar was higher than that of pristine $\mathrm{Mg}$-Al-LDH. Moreover, the adsorption of MG on $\mathrm{Mg}-\mathrm{Al} /$ Biochar, which was dominated by

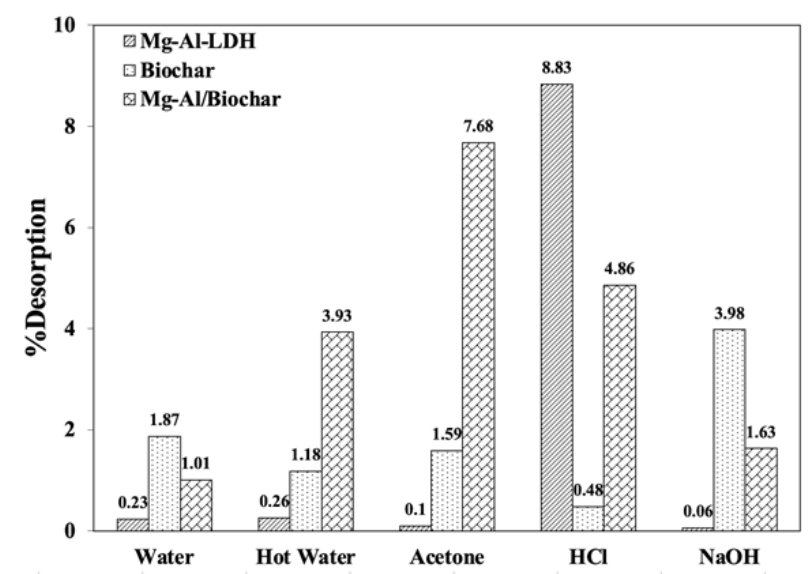

Figure 12. Malachite green desorption from $\mathrm{Mg}$-Al-layered double hydroxide (LDH), biochar, and $\mathrm{Mg}-\mathrm{Al} / \mathrm{Biochar}$. physical adsorption, followed the PSO kinetic and Freundlich isotherm models. The adsorption energy of $\mathrm{Mg}-\mathrm{Al} / \mathrm{Biochar}$ ranged between $5.531-38.024 \mathrm{~kJ} / \mathrm{mol}$, which further confirmed the predominant physical nature of the adsorption process. Furthermore, Mg-Al/Biochar presented a highly stable structure and was reused for three adsorption cycles with negligible changes in adsorption capacity.

\section{Acknowledgment}

The study was supported financially by Hibah Profesi 2020-2021 Universitas Sriwijaya (grant no. 0687/UN9/SK.BUK.KP/2020). The authors would like to thank the researchers at the Research Center of Inorganic Materials and Complexes FMIPA Universitas Sriwijaya for allowing us access to the equipment required to perform this research.

\section{References}

[1] Santhi, T., Manonmani, S., Smitha, T. (2010). Removal of methyl red from aqueous solution by activated carbon prepared from the $A n$ nona squmosa seed by adsorption. Chemical Engineering Research Bulletin, 14, 11-18, doi: 10.3329/cerb.v14i1.3767

[2] Méndez, A., Fernández, F., Gascó, G. (2007). Removal of malachite green using carbonbased adsorbents. Desalination, 206, 147153, doi: 10.1016/j.desal.2006.03.564

[3] Mahmoud, R.K., Kotp, A.A., El-Deen, A.G.A., Farghali, A., Abo El-Ela, F.I. (2020). Novel and Effective Zn-Al-GA LDH Anchored on Nanofibers for High-Performance Heavy Metal Removal and Organic Decontamination: Bioremediation Approach. Water, Air, and Soil Pollution, 231, 363, doi: 10.1007/s11270020-04629-4

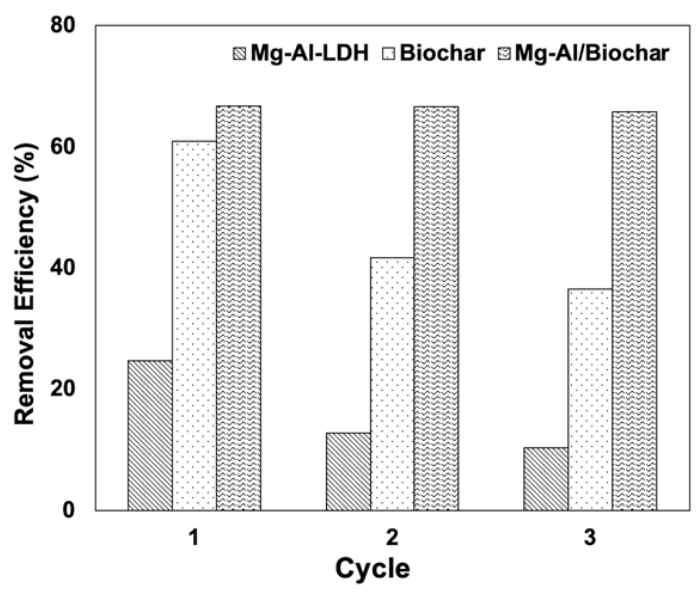

Figure 13. Malachite green regeneration from Mg-Al-layered double hydroxide (LDH), biochar, and $\mathrm{Mg}-\mathrm{Al} /$ Biochar. 
[4] Islam, M.A., Ali, I., Karim, S.M.A., Hossain Firoz, M.S., Chowdhury, A.N., Morton, D.W., Angove, M.J. (2019). Removal of dye from polluted water using novel nano manganese oxide-based materials. Journal of Water Process Engineering, $32, \quad 100911$, doi: 10.1016/j.jwpe.2019.100911

[5] Schwarzenbach, R.P., Egli, T., Hofstetter, T.B., von Gunten, U., Wehrli, B. (2010). Global Water Pollution and Human Health. Annual Review of Environment and Resources, 35, 109-136, doi: 10.1146/annurev-environ100809-125342

[6] Haile, H.L., Abi, T., Tesfahun, K. (2015). Synthesis, characterization and photocatalytic activity of $\mathrm{MnO} 2 / \mathrm{Al} 2 \mathrm{O} 3 / \mathrm{Fe} 2 \mathrm{O} 3$ nanocomposite for degradation of malachite green. African Journal of Pure and Applied Chemistry, 9, 211-222, doi: 10.5897/ajpac2015.0656

[7] Zhang, P., Connor, D.O., Wang, Y., Jiang, L., Xia, T., Wang, L., Tsang, D.C.W., Sik, Y., Hou, D. (2020). A green biochar / iron oxide composite for methylene blue removal. Journal of Hazardous Materials, 384, 121286, doi: 10.1016/j.jhazmat.2019.121286

[8] Lü, Z., Hu, F., Li, H., Zhang, X., Yu, S., Liu, M., Gao, C. (2019). Composite nanofiltration membrane with asymmetric selective separation layer for enhanced separation efficiency to anionic dye aqueous solution. Journal of Hazardous Materials, 19, 436-443, doi: 10.1016/j.jhazmat.2019.01.086

[9] Youssef, N.A., Shaban, S.A., Ibrahim, F.A., Mahmoud, A.S. (2016). Degradation of methyl orange using Fenton catalytic reaction. Egyptian Journal of Petroleum, 25, 317-321 doi: 10.1016/j.ejpe.2015.07.017

[10] Vinsiah, R., Mohadi, R., Lesbani, A. (2020). Performance of Graphite for Congo Red and Direct Orange Adsorption. Indonesian Journal of Environmental Management and Sustainability. 4, 125-132, doi: 10.26554/ijems.2020.4.4.125-132

[11] Ríos-Badrán, I.M., Luzardo-Ocampo, I., García-Trejo, J.F., Santos-Cruz, J., GutiérrezAntonio, C. (2020). Production and characterization of fuel pellets from rice husk and wheat straw. Renewable Energy, 145, 500 507, doi: 10.1016/j.renene.2019.06.048

[12] Tang, H., Zhou, W., Zhang, L. (2012). Adsorption isotherms and kinetics studies of malachite green on chitin hydrogels. Journal of Hazardous Materials, 209-210, 218-225, doi: 10.1016/j.jhazmat.2012.01.010

[13] Arabkhani, P., Asfaram, A. (2020). Development of a novel three-dimensional magnetic polymer aerogel as an efficient adsorbent for malachite green removal. Journal of Hazardous Materials, 384, 121394, doi: 10.1016/j.jhazmat.2019.121394

[14] Vimonses, V., Lei, S., Jin, B., Chow, C.W.K., Saint, C. (2009). Kinetic study and equilibrium isotherm analysis of Congo Red adsorption by clay materials. Chemical Engineering Journal, 148, 354-364, doi: 10.1016/j.cej.2008.09.009

[15] Theresa, M., Ginting, S. (2017). Impregnation of bentonite with cellulose as adsorbent of congo red. Science and Technology Indonesia, 2, 37-44, doi: 10.26554/sti.2017.2.2.37-44

[16] Zubair, M., Manzar, M.S., Mu'azu, N.D., Anil, I., Blaisi, N.I., Al-Harthi, M.A. (2020). Functionalized $\mathrm{MgAl}$-layered hydroxide intercalated date-palm biochar for Enhanced Uptake of Cationic dye: Kinetics, isotherm and thermodynamic studies. Applied Clay Science, 190, 105587, doi: 10.1016/j.clay.2020.105587

[17] Daud, M., Hai, A., Banat, F., Wazir, M.B., Habib, M., Bharath, G., Al-Harthi, M.A. (2019). A review on the recent advances, challenges and future aspect of layered double hydroxides (LDH) - Containing hybrids as promising adsorbents for dyes removal. Journal of Molecular Liquids, 288, 110989, doi: 10.1016/j.molliq.2019.110989

[18] Qu, J., Sha, L., Wu, C., Zhang, Q. (2019). Applications of mechanochemically prepared layered double hydroxides as adsorbents and catalysts: A mini-review. Nanomaterials, 9, 1-15, doi: 10.3390/nano9010080

[19] Ouassif, H., Moujahid, E.M., Lahkale, R., Sadik, R., Bouragba, F.Z., Sabbar, E., Diouri, M. (2020). Zinc-Aluminum layered double hydroxide: High efficient removal by adsorption of tartrazine dye from aqueous solution. Surfaces and Interfaces, 18, 100401, doi: 10.1016/j.surfin.2019.100401

[20] De Sá, F.P., Cunha, B.N., Nunes, L.M. (2013). Effect of $\mathrm{pH}$ on the adsorption of Sunset Yellow FCF food dye into a layered double hydroxide (CaAl-LDH-NO3). Chemical Engineering Journal, 215-216, 122-127, doi: 10.1016/j.cej.2012.11.024

[21] Lesbani, A., Asri, F., Palapa, N.R., Taher, T., Rachmat, A. (2020). Efficient removal of methylene blue by adsorption using composite based $\mathrm{Ca} / \mathrm{Al}$ layered double hydroxidebiochar. Global NEST Journal, 22, 250-257, doi: 10.30955/gnj.003359

[22] El Gaini, L., Lakraimi, M., Sebbar, E., Meghea, A., Bakasse, M. (2009). Removal of indigo carmine dye from water to $\mathrm{Mg}$-Al-CO3calcined layered double hydroxides. Journal of Hazardous Materials, 161, 627-632, doi: 10.1016/j.jhazmat.2008.04.089 
[23] Lafi, R., Charradi, K., Djebbi, M.A., Ben Haj Amara, A., Hafiane, A. (2016). Adsorption study of Congo red dye from aqueous solution to Mg-Al-layered double hydroxide. Advanced Powder Technology, 27, 232-237, doi: 10.1016/j.apt.2015.12.004

[24] Hu, H., Wageh, S., Al-Ghamdi, A.A., Yang, S., Tian, Z., Cheng, B., Ho, W. (2020). NiFe-LDH nanosheet/carbon fiber nanocomposite with enhanced anionic dye adsorption performance. Applied Surface Science, 511, 145570, doi: 10.1016/j.apsusc.2020.145570

[25] Meili, L., Lins, P.V., Zanta, C.L.P.S., Soletti, J.I., Ribeiro, L.M.O., Dornelas, C.B., Silva, T.L., Vieira, M.G.A. (2019). MgAlLDH/Biochar composites for methylene blue removal by adsorption. Applied Clay Science, 168, 11-20, doi: 10.1016/j.clay.2018.10.012

[26] Zubair, M., Saood, M., Dalhat, N., Anil, I. (2020). Applied Clay Science Functionalized MgAl-layered hydroxide intercalated datepalm biochar for Enhanced Uptake of Cationic dye : Kinetics, isotherm and thermodynamic studies. Applied Clay Science, 190, 105587, doi: 10.1016/j.clay.2020.105587

[27] Amin, M.T., Alazba, A.A., Shafiq, M. (2020). $\mathrm{LDH}$ of $\mathrm{NiZnFe}$ and its composites with carbon nanotubes and data-palm biochar with efficient adsorption capacity for RB5 dye from aqueous solutions: Isotherm, kinetic, and thermodynamics studies. Current Applied Physics, (Article in Press), Available online 31 July 2020, doi: 10.1016/j.cap.2020.07.005

[28] Palapa, N.R., Taher, T., Rahayu, B.R., Mohadi, R., Rachmat, A., Lesbani, A. (2020). $\mathrm{CuAl}$ LDH/Rice Husk Biochar Composite for Enhanced Adsorptive Removal of Cationic Dye from Aqueous Solution. Bulletin of Chemical Reaction Engineering \& Catalysis, 15(2), 525-537, doi: 10.9767/bcrec.15.2.7828.525-537

[29] Pang, X., Chen, L., Liu, Y., Chi, M., Li, Z., Plank, J. (2017). Growth behavior of water dispersed MgAl layered double hydroxide nanosheets. RSC Advances, 7, 14989-14997, doi: 10.1039/C7RA00833C

[30] Lins, P.V.S., Henrique, D.C., Ide, A.H., da silva Duarte, J.L., Dotto, G.L., Yazidi, A., Sellaoui, L., Erto, A., Zanta, C.L.d.P.e.S., Meili, L. (2020). Adsorption of a non-steroidal anti-inflammatory drug onto $\mathrm{MgAl} / \mathrm{LDH}$ activated carbon composite - Experimental investigation and statistical physics modeling. Colloids and Surfaces A: Physicochemical and Engineering Aspects, 586, 124217, doi: 10.1016/j.colsurfa.2019.124217

[31] Kang, D., Yu, X., Tong, S., Ge, M., Zuo, J., Cao, C., Song, W. (2013). Performance and mechanism of $\mathrm{Mg} / \mathrm{Fe}$ layered double hydroxides for fluoride and arsenate removal from aqueous solution. Chemical Engineering Journal, 228, 731-740, doi: 10.1016/j.cej.2013.05.041

[32] Clark, I., Smith, J., Gomes, R.L., Lester, E. (2019). Continuous Synthesis of Zn2Al-CO3 Layered Double Hydroxides for the Adsorption of Reactive Dyes from Water. Journal of Environmental Chemical Engineering, 7, 2213-2929, doi : 10.1016/j.jece.2019.103175

[33] Modwi, A., Abbo, M.A., Hassan, E.A., AlDuaij, O.K., Houas, A. (2017). Adsorption kinetics and photocatalytic degradation of malachite green (MG) via $\mathrm{Cu} / \mathrm{ZnO}$ nanocomposites. Journal of Environmental Chemical Engineering, 5, 5954-5960, doi: 10.1016/j.jece.2017.11.024

[34] Huang, Q., Song, S., Chen, Z., Hu, B., Chen, J., Wang, X. (2019). Biochar-based materials and their applications in removal of organic contaminants from wastewater: state-of-theart review. Biochar, 1, 45-73, doi: 10.1007/s42773-019-00006-5

[35] Khan, M.A., Alqadami, A.A., Otero, M., Siddiqui, M.R., Alothman, Z.A., Alsohaimi, I., Rafatullah, M., Hamedelniel, A.E. (2019). Heteroatom-doped magnetic hydrochar to remove post-transition and transition metals from water: Synthesis, characterization, and adsorption studies. Chemosphere, 218, 10891099, doi: 10.1016/j.chemosphere.2018.11.210

[36] Menya, E., Olupot, P.W., Storz, H., Lubwama, M., Kiros, Y., John, M.J. (2020). Optimization of pyrolysis conditions for char production from rice husks and its characterization as a precursor for production of activated carbon. Biomass Conversion and Biorefinery, 10, 57-72, doi: 10.1007/s13399-019-00399-0

[37] Palapa, N.R., Juleanti, N.N., Mohadi, R., Taher, T., Rachmat, A., Lesbani, A. (2020). Copper Aluminum Layered Double Hydroxide Modified by Biochar and its Application as an Adsorbent for Procion Red. Journal of Water and Environment Technology, 18, 359-371, doi: 10.2965/JWET.20-059

[38] Ahmed, D.N., Naji, L.A., Faisal, A.A.H., AlAnsari, N., Naushad, M. (2020). Waste foundry sand/MgFe-layered double hydroxides composite material for efficient removal of Congo red dye from aqueous solution. Scientific Reports, 10, 1-12, doi: 10.1038/s41598-02058866-y

[39] Qu, W., Yuan, T., Yin, G., Xu, S., Zhang, Q., $\mathrm{Su}, \mathrm{H}$. (2019). Effect of properties of activated carbon on malachite green adsorption. Fuel, 249, 45-53, doi: 10.1016/j.fuel.2019.03.058

[40] Lee, Y.C., Amini, M.H.M., Sulaiman, N.S., Mazlan, M., Boon, J.G. (2018). Batch adsorption and isothermic studies of malachite 
green dye adsorption using leucaena leucocephala biomass as potential adsorbent in water treatment. Songklanakarin Journal of Science and Technology, 40, 563-569, doi: 10.14456/sjst-psu.2018.67

[41] Segun Esan, O. (2019). The Removal of Single and Binary Basic Dyes from Synthetic Wastewater Using Bentonite Clay Adsorbent. American Journal of Polymer Science and Technology, $5, \quad 16, \quad \mathrm{~d}$ o i : 10.11648/j.ajpst.20190501.13

[42] Abdel Salam, M., Abukhadra, M.R., Adlii, A. (2020). Insight into the Adsorption and Photocatalytic Behaviors of an Organobentonite/CO3O4 Green Nanocomposite for Malachite Green Synthetic Dye and $\mathrm{Cr}(\mathrm{VI})$ Metal Ions: Application and Mechanisms. ACS Omega, 5, 6, 2766-2778, doi: 10.1021/acsomega.9b03411

[43] Biswas, S., Sharma, S., Mukherjee, S., Meikap, B.C., Sen, T.K. (2020). Process modelling and optimization of a novel Semifluidized bed adsorption column operation for aqueous phase divalent heavy metal ions removal. Journal of Water Process Engineering, Elsevier. $\quad 37, \quad 101406, \quad$ doi : 10.1016/j.jwpe.2020.101406

[44] Rajabi, M., Mirza, B., Mahanpoor, K., Mirjalili, M., Najafi, F., Moradi, O., Sadegh, H., Shahryari-ghoshekandi, R., Asif, M., Tyagi, I., Agarwal, S., Gupta, V.K. (2016). Adsorption of malachite green from aqueous solution by carboxylate group functionalized multi-walled carbon nanotubes: Determination of equilibrium and kinetics parameters. Journal of Industrial and Engineering Chemistry, 34, 130138, doi: 10.1016/j.jiec.2015.11.001

[45] George, G., Saravanakumar, M.P. (2018). Facile synthesis of carbon-coated layered double hydroxide and its comparative characterisation with $\mathrm{Zn}-\mathrm{Al} \mathrm{LDH}$ : application on crystal violet and malachite green dye adsorptionisotherm, kinetics and Box-Behnken design. Environmental Science and Pollution Research, 25, 30236-54, doi: 10.1007/s11356018-3001-3

[46] Nasiri Azad, F., Ghaedi, M., Dashtian, K., Hajati, S., Goudarzi, A., Jamshidi, M. (2015). Enhanced simultaneous removal of malachite green and safranin $\mathrm{O}$ by $\mathrm{ZnO}$ nanorod-loaded activated carbon: Modeling, optimization and adsorption isotherms. New Journal of Chemistry, 39, 7998-8005, doi: 10.1039/c5nj01281c
[47] Mashkoor, F., Nasar, A. (2019). Preparation, characterization and adsorption studies of the chemically modified Luffa aegyptica peel as a potential adsorbent for the removal of malachite green from aqueous solution. Journal of Molecular Liquids, 274, 315-327, doi: 10.1016/j.molliq.2018.10.119

[48] Rangabhashiyam, S., Balasubramanian, P. (2018). Performance of novel biosorbents prepared using native and $\mathrm{NaOH}$ treated Peltophorum pterocarpum fruit shells for the removal of malachite green. Bioresource Technology Reports, 3, 75-81, doi: 10.1016/j.biteb.2018.06.004

[49] Lesbani, A., Taher, T., Palapa, N.R., Mohadi, R., Rachmat, A., Mardiyanto. (2020). Preparation and utilization of Keggin-type polyoxometalate intercalated $\mathrm{Ni}-\mathrm{Fe}$ layered double hydroxides for enhanced adsorptive removal of cationic dye. SN Applied Sciences, 2, 4-7, doi: $10.1007 / \mathrm{s} 42452-020-2300-8$

[50] Amin, R.M., Taha, M., Abdel Moaty, S.A., Abo El-Ela, F.I., Nassar, H.F., Gadelhak, Y., Mahmoud, R.K. (2019). Gamma radiation as a green method to enhance the dielectric behaviour, magnetization, antibacterial activity and dye removal capacity of $\mathrm{Co}-\mathrm{Fe} \mathrm{LDH}$ nanosheets. RSC Advances, 9, 32544-92561, doi: 10.1039/c9ra06509a

[51] Palapa, N.R., Mohadi, R., Rachmat, A., Lesbani, A. (2020). Adsorption Study of Malachite Green Removal from Aqueous Solution Using $\mathrm{Cu} / \mathrm{M} 3+(\mathrm{M} 3+=\mathrm{Al}, \mathrm{Cr})$ Layered Double Hydroxide. Mediterranean Journal of Chemistry, $10, \quad 33-45, \quad \mathrm{doi}$ : 10.13171/mjc10102001261236al

[52] Sriram, G., Uthappa, U.T., Losic, D., Kigga, M., Jung, H.Y., Kurkuri, M.D. (2020). Mg-Allayered double hydroxide ( $\mathrm{LDH})$ modified diatoms for highly efficient removal of Congo red from aqueous solution. Applied Sciences, 10(7), 2285, doi: 10.3390/app10072285 